\title{
Alsea Formation-an Oligocene Marine Sedimentary Sequence In the Oregon Coast Range
}

GE O L O G I C A L S U R V E Y B ULLETIN 1395 - F

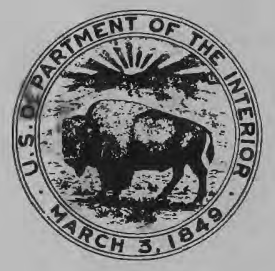





\section{Alsea Formation-an Oligocene Marine Sedimentary Sequence In the Oregon Coast Range}

By P. D. SNAVELY, JR., N. S. MAcLEOD, W. W. RAU, W. O. ADDICOTT, and J. E. PEARL CONTRIBUTIONS TO STRATIGRAPHY GE O L O G I C A L S U R V E Y B U L L E T I N $1395-\mathrm{F}$

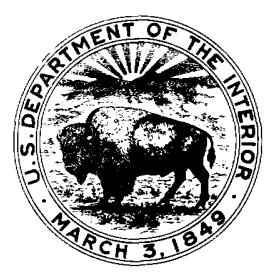




\title{
UNITED STATES DEPARTMENT OF THE INTERIOR
}

\author{
ROGERS C. B. MORTON, Secretary
}

\section{GEOLOGICAL SURVEY}

V. E. McKelvey, Director

Library of Congress Cataloging in Publication Data

Alsea Formation, an Oligocene marine sedimentary

sequence in the Oregon Coast Range.

(Contributions to Stratigraphy) (Geological Survey

Bulletin 1395-F)

Bibliography: p. 20-21.

Supt. of Docs. No.: I 19.3:1395-F

1. Geology, Stratigraphic-Oligocene. 2. Sediments (Geology)-Oregon-Coast

Range. I. Snavely, Parke Detweiler, 1919- II. Series. III. Series: United

States Geological Survey Bulletin 1395-F.

QE75.B9 No. 1395-F [QE693] 557.3'08s [551.7'8]

74-34338

For sale by the Superintendent of Documents, U. S. Government Printing Office

Washington, D. C. 20402

Stock Number $024-001-02605$ 


\section{CONTENTS}

$\begin{array}{lr}\text { Abstract } & \text { Page } \\ \text { Introduction } & \text { F1 } \\ \text { Acknowledgment } & \text { Geologic setting } \\ \text { Physical characteristics } & 7 \\ \text { Age and depositional environment } & 8 \\ \text { Regional correlations and paleogeology } & 10 \\ \text { References cited } & \end{array}$

\section{ILLUSTRATIONS}

Figure 1. Bedrock geologic map of the central Oregon coast

2. Geologic map showing distribution of the Alsea Formation at its type locality on Alsea Bay

3. Geologic map showing the distribution of the Alsea Formation at its reference section along the Yaquina River

4. Photograph of tuffaceous siltstone and sandstone of the Alsea Formation at its type section on the north side of Alsea Bay

5. Photomicrograph showing the abundant vesicular glass fragments and glass shards that characterize siltstone and sandstone of the Alsea Formation

6. Photograph showing Oligocene mollusks from the Alsea Formation, Lincoln County

7. Paleogeologic map of western Oregon and Washington in Oligocene time

\section{TABLE}

TABLE 1. Chemical analyses of selected sedimentary rocks from the Alsea Formation 



\title{
ALSEA FORMATION- AN OLIGOCENE MARINE SEDIMENTARY SEQUENCE IN THE OREGON COAST RANGE
}

\author{
By P. D. Snavely, Jr., N. S. Macleod, W. W. Rau, \\ W. O. Addicott, and J. E. Pearl
}

\begin{abstract}
The Alsea Formation, named in this report, crops out in a $65-\mathrm{km}$-long arcuate belt along the central Oregon coast, where it occurs in the upper part of a 6,000-m-thick Tertiary marine sequence that forms the Coast Range. The Alsea Formation consists principally of marine tuffaceous siltstone and very fine grained sandstone but also contains interbedded mudstone, glauconitic sandstone, fine-grained tuff, and reworked lapilli tuff. Abundant molluscan and foraminiferal faunas indicate an early (upper Refugian- "Lincoln" Stage) to late (Zemorrian-lower "Blakeley" stage) Oligocene age and an upper bathyal and sublittoral depositional environment. The Alsea Formation ranges in thickness from 50 to $1,100 \mathrm{~m}$. It shows an inverse thickness relation to deltaic sandstone of the overlying upper Oligocene and lower Miocene Yaquina Formation that results partly from lateral interfingering of the upper part of the Alsea with the lower part of the Yaquina. The Alsea Formation and correlative units in western Oregon and Washington formed along a continental shelf that lay west of a volcanically active ancestral Cascade Range.
\end{abstract}

\section{INTRODUCTION}

Marine sedimentary rocks of Oligocene age form a westwarddipping arcuate outcrop belt open to the Pacific Ocean along the central Oregon coast (fig. 1). A revision of Oligocene stratigraphic nomenclature in this area has awaited detailed geologic mapping (Snavely and others, 1975a, b, c) in order to demonstrate the regional distribution of lithologic units. This report describes and names the sequence of tuffaceous siltstone and fine-grained sandstone that forms the lower part of the Oligocene sequence of coastal Oregon. These strata are here named the Alsea Formation for excellent exposures along the shores of Alsea Bay. The type section is designated as exposures along the north side of Alsea Bay between points $A$ and $B$ on the geologic map (fig. 2) and on the south side of the bay between $\mathrm{C}$ and D. A precise stratigraphic correlation is difficult to make between the 


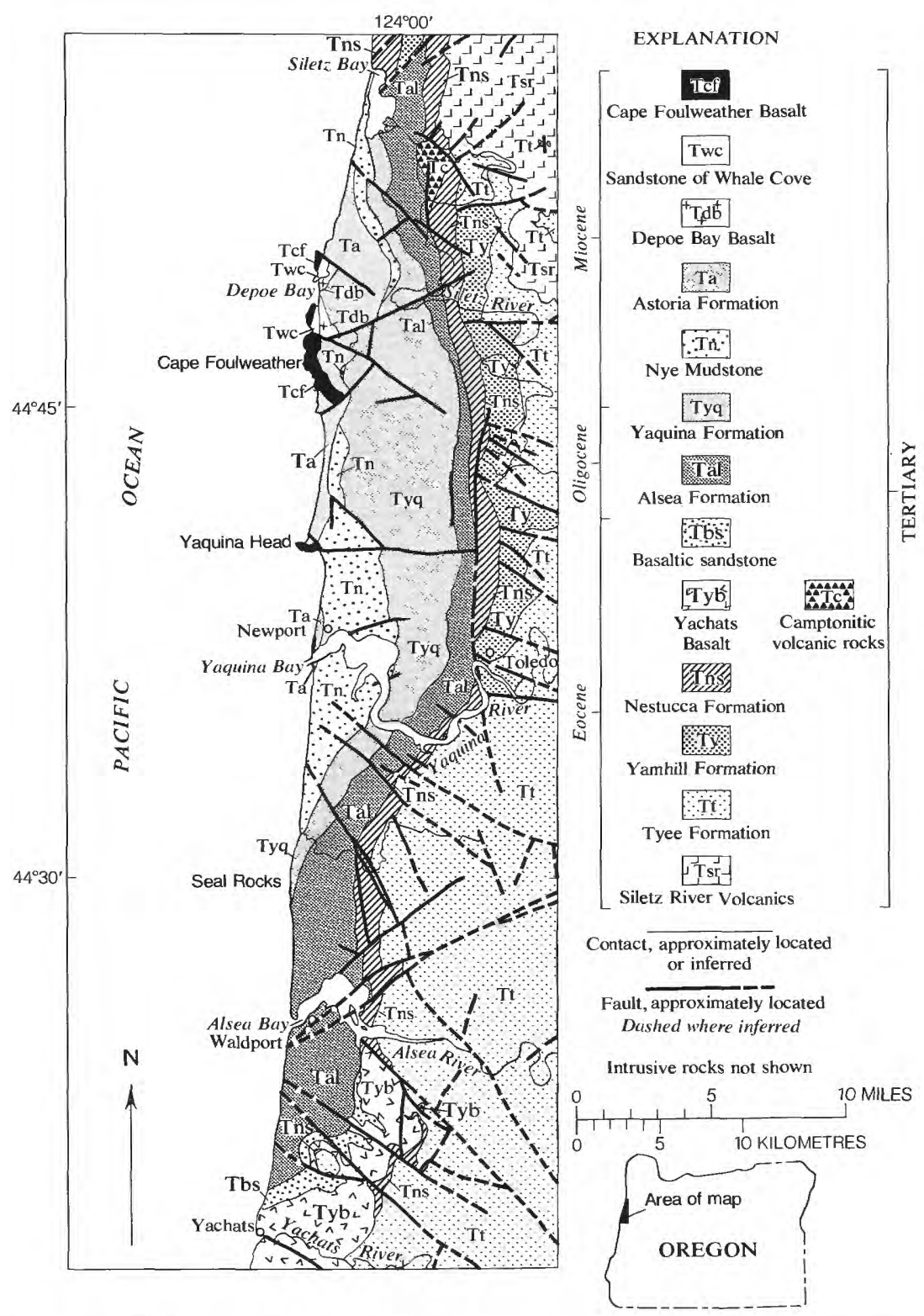

FigURE 1.-Bedrock geology of central Oregon coast showing the relation of the Alsea Formation to other Tertiary units.

parts of the Alsea Formation that crop out on the north and south sides of Alsea Bay. Distinctive lithologic units that occur in the section along the north side of the bay, as the glauconitic sandstone bed at 
point $\mathrm{G}$ in figure 2 , have not been recognized on the south side. Faulting in the bay further complicates correlation of strata across the bay. On the basis of lithologic and faunal similarities, the siltstone exposed at the top of the exposed section (A, fig. 2) on the north side of the bay is considered to correlate with the lower part of the siltstone unit (D, fig. 2 ) that crops out on the south side of the bay.

The lower part of the Alsea Formation is covered by Quaternary deposits along the bay but is exposed along county and logging roads north and south of the bay. The upper part of the Alsea Formation crops out along the south side of the entrance to Alsea Bay (C, fig. 2), but its contact with the overlying Yaquina Formation is not exposed there. Although the formation is thickest at the type section, its contact relations are best seen along the Yaquina River, $17 \mathrm{~km}$ to the north. Therefore, a reference section is designated as those outcrops and road cuts along the north side of the Yaquina River from the base of the formation at $B$ westward to its top at $A$ on the map of the section (fig. 3).

On the basis of stratigraphic studies along the Yaquina River, Harrison and Eaton (1920) included tuffaceous siltstone and sandstone, the Alsea Formation of this report, in the upper part of their newly named Toledo division. The lower part of their Toledo division included thin-bedded to massive siltstone and interbedded glauconitic sandstone, later named the Moody Shale by Schenck (1927). Although Vokes, Norbisrath, and Snavely (1949) recognized the Eocene age of the Moody, they included it with the overlying tuffaceous sandstone and siltstone (Alsea Formation of this report) in their Toledo Formation. They stated, however, that future work would probably raise both lithologic units to formational rank. Mapping by Snavely, MacLeod, Wagner, and Rau (1975a, b, c) has shown that the lower part of the Toledo Formation, the Moody Shale Member, includes both the Yamhill Formation of late middle and late Eocene age and the Nestucca Formation of latest Eocene age and that the upper part of the Toledo Formation is the Alsea Formation of this report. The names Toledo Formation and Moody Shale Member are therefore considered obsolete.

Schenck (1928) described the stratigraphy and a few fossils of the well-exposed Oligocene sequence, the Alsea Formation of this report, at its type section on the north and south sides of Alsea Bay. $\mathrm{He}$ correctly assigned strata in the lower part of the sequence an early and middle Oligocene age, but assigned a Miocene age to the siltstone at the top of the sequence that is now known to be of late Oligocene age. On the basis of lithology, stratigraphic position, and selected fossils, he correlated his Oligocene strata on Alsea Bay with the type Toledo 

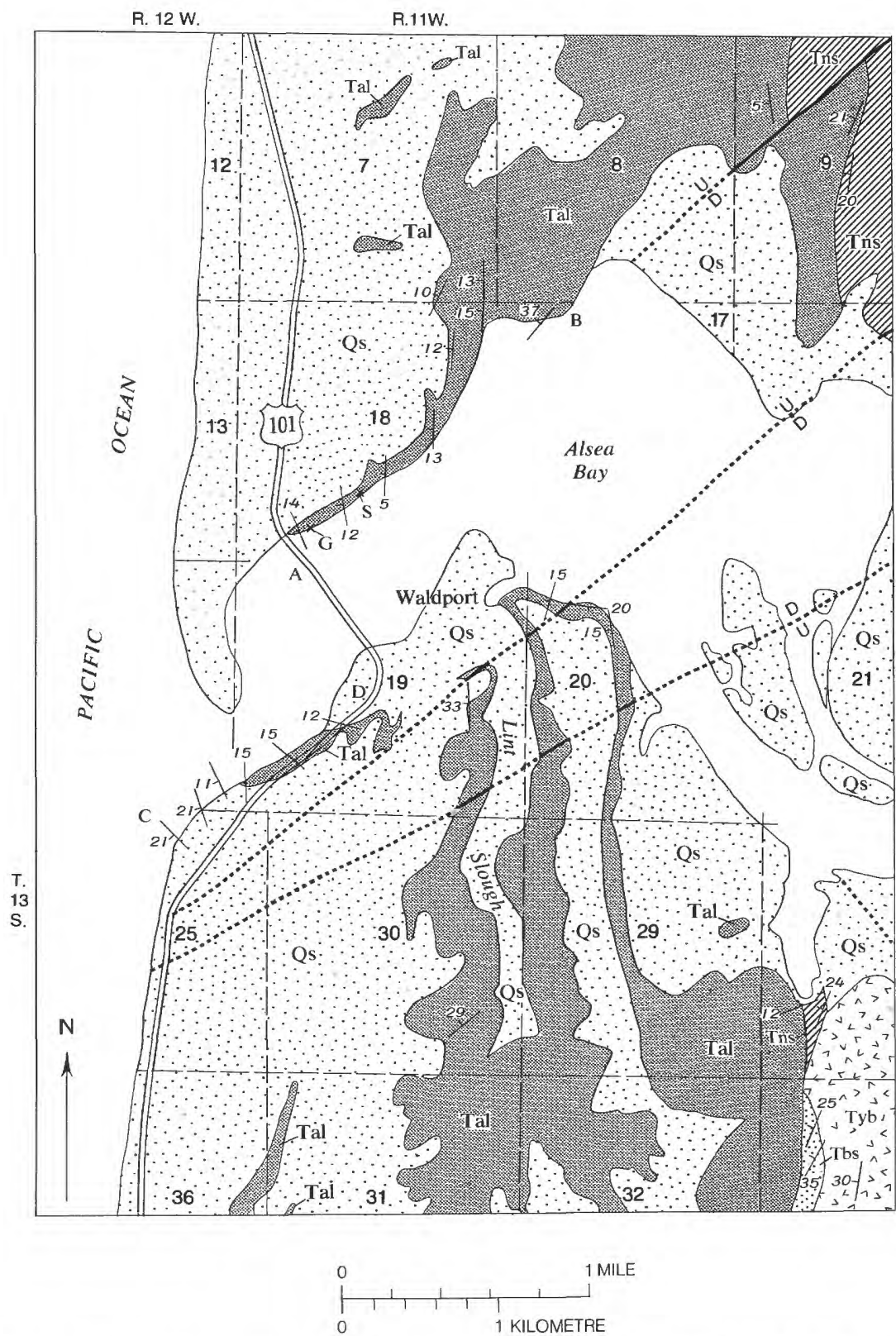

FIGURE 2.-Distribution of the Alsea Formation at its type locality on Alsea Bay. Lower part of Alsea Formation is exposed between A and B, upper part between C and D. Glauconitic sandstone bed $(G)$ and massive sandstone (S) are referred to in text. Attitudes in the Alsea Formation near point $\mathrm{C}$ are from scattered outcrops that are intermittently exposed below beach sand. 
Formation on the Yaquina River. Vokes, Norbisrath, and Snavely (1949) included the lower part of the Alsea Formation of this report along Alsea Bay in the upper part of their Toledo Formation and the upper part of the Alsea in their Yaquina Formation.

The tuffaceous siltstone and sandstone of Oligocene age that crops out in the west-central part of the Oregon Coast Range has been informally referred to as "siltstone of Alsea" in reports and on geologic maps by Snavely, MacLeod, and Rau (1969), Snavely, MacLeod, and Wagner (1972a, b, c), and MacLeod and Snavely (1973). These strata are here raised to formational rank, as they make up an important lithologic unit that has been mapped for more than $65 \mathrm{~km}$ along the west side of the central Oregon Coast Range (fig. 1).

\section{ACKNOWLEDGMENT}

The writers express their appreciation to Paula J. Quinterno for her assistance in the preparation of this report.

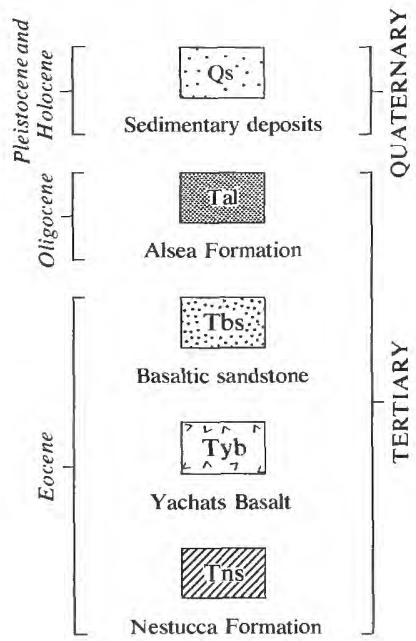

Contact, approximately located

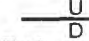

Fault, approximately located

Dotted where concealed or inferred. $\mathrm{U}$, upthrown side $; \mathrm{D}$, downthrown side

30

Strike and dip of beds

Figure 2.-Continued. 

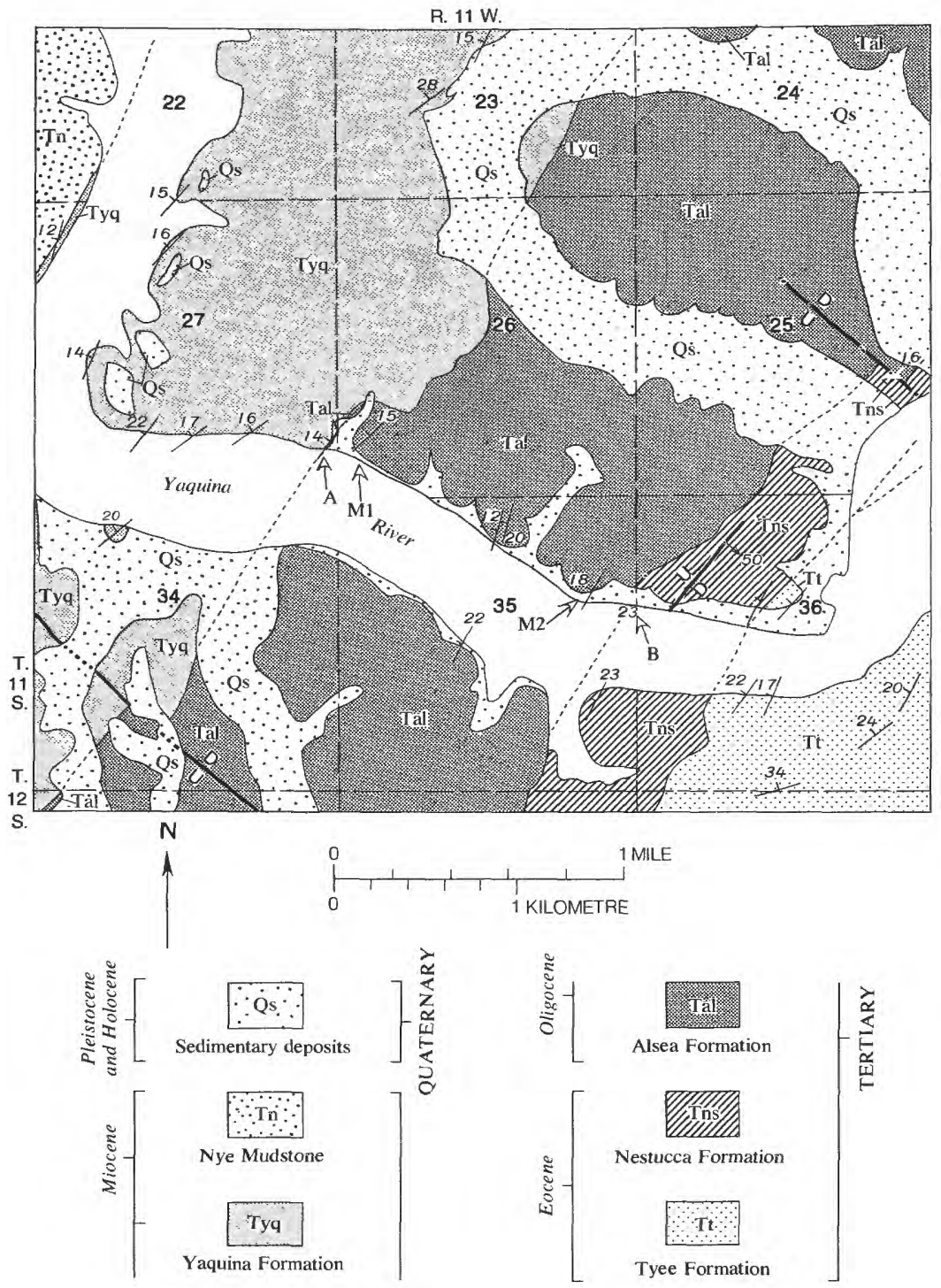

Contact, approximately located. Dotted where concealed or inferred
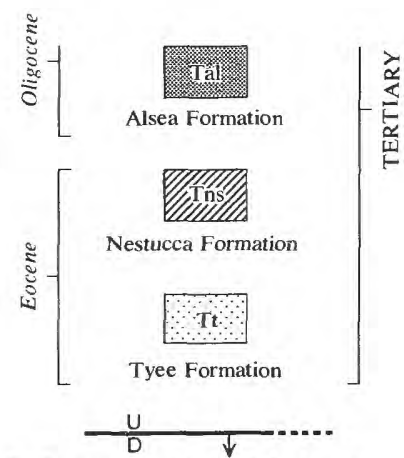

Fault, approximately located, showing dip. Dotted where concealed or inferred. $U$, upthrown side; $D$, downthrown side

Strike and dip of beds

FIGURE 3.-Distribution of the Alsea Formation at its reference section A-B along the Yaquina River. M1 and M2 are molluscan localities referred to in text. 


\section{GEOLOGIC SETTING}

The Alsea Formation occurs in the upper part of a Tertiary sequence of marine sedimentary and volcanic rocks more than $6,000 \mathrm{~m}$ thick that crops out in the central part of the Oregon Coast Range. The Alsea Formation forms a narrow arcuate belt near the coast from near Yachats northward about $65 \mathrm{~km}$ to Siletz Bay (fig. 1).

Contacts between the Alsea Formation and underlying and overlying strata are well exposed in the reference section along the Yaquina River (fig. 3). Here, and throughout most of its area of outcrop, the massive to thick-bedded tuffaceous siltstone and sandstone of the Alsea Formation conformably overlies thin-bedded siltstone, the Nestucca Formation of late Eocene age. The contact is usually gradational over a few metres but in places is sharply defined. Glauconitic sandstone is locally present at the base of the Alsea Formation. In the northern part of its outcrop area, near Siletz Bay, the Alsea Formation rests on alkaline volcanic rocks that are interbedded in the upper part of the Nestucca Formation. In the southernmost area of outcrop, the Alsea Formation conformably overlies an unnamed basaltic sandstone unit of latest Eocene age that was derived from the underlying Yachats Basalt (Snavely and MacLeod, 1974). The Alsea Formation is overlain conformably by a predominantly sandstone sequence, the Yaquina Formation of late Oligocene and early Miocene age (fig. 1). In most places the tuffaceous siltstone of the Alsea Formation interbeds upward with coarse-grained sandstone of the Yaquina Formation; locally, however, a sharp contact is present between the two units.

The Alsea Formation ranges in thickness from $50 \mathrm{~m}$ to $1,100 \mathrm{~m}$ and shows an inverse thickness relation to the overlying Yaquina Formation. Where the broad, lenslike body of Yaquina sandstone is thickest near lat $44^{\circ} 45^{\prime}$, the Alsea Formation is only 50-100 m thick; conversely, where the Yaquina Formation thins north and south of this area, the Alsea Formation increases in thickness to as much as 1,100 $\mathrm{m}$. This inverse thickness variation of the two formations results in part from a lateral gradation of the moderately deep water siltstone of the upper part of the Alsea Formation with coarse-grained clastic deltaic sedimentary rocks of the lower part of the Yaquina Formation. A thinning of the lower part of the Alsea Formation and of the underlying Nestucca Formation near lat $44^{\circ} 45^{\prime}$ probably resulted from a slow rate of sedimentation over a broad bathymetric high that occupied this area in late Eocene to middle Oligocene time. Westward, on the Continental Shelf, the Yaquina Formation must also grade laterally into siltstone, as it was not encountered in the Standard-Union Nautilus test well, drilled about $18 \mathrm{~km}$ off Depoe Bay (Braislin and others, 1971, fig. 4). In this well more than $1,800 \mathrm{~m}$ of siltstone correlative with the 
Alsea Formation occupies the entire Oligocene sequence and is overlain by the lower Miocene Nye Mudstone.

\section{PHYSICAL CHARACTERISTICS}

The Alsea Formation typically consists of fossiliferous massive to medium-bedded tuffaceous siltstone and very fine grained sandstone (fig. 4). A few beds of massive mudstone are present in the sequence. The siltstone is ubiquitously tuffaceous, and beds of essentially pure fine-grained tuff $2 \mathrm{~cm}$ to $1 \mathrm{~m}$ thick are present. Interbeds of pumiceous lapilli tuff and glauconitic sandstone occur locally. Calcareous concretions and nodules, commonly alined parallel to bedding, occur in many outcrops. These concretions, typically $4-10 \mathrm{~cm}$ in diameter, commonly contain mollusks or fossil crabs in their cores. Clastic dikes were noted in only one outcrop near the east city limits of Waldport, whereas they are abundant in the underlying Nestucca Formation.

Where freshly exposed, the tuffaceous siltstone and sandstone is dark to medium greenish gray and weathers spheroidally to a mottled light gray and light orange brown. The rock has a hackly to conchoidal fracture and is broken by numerous small irregular joints, commonly stained by hydrous iron exides and sulfates. The tuffaceous siltstone contains scattered lithic and glauconite grains; Foraminifera and fish scales are present in many samples.

The sandstone commonly contains fine mica, carbonaceous material, and pumice fragments. Thin beds of pebble conglomerate composed of pumice and andesitic volcanic rocks occur locally. Although most of the sandstone is massive to thick bedded, a unit of thin-bedded tuffaceous sandstone and siltstone occurs in the lower part of the Alsea Formation on the north side of Alsea Bay (SW11/4, sec. 8, T. 13 S., R. 11 W.). A lenslike unit of glauconitic and arkosic sandstone, as much as $60 \mathrm{~m}$ thick, is interbedded in siltstone of the Alsea Formation along the east of Siletz Bay in the northernmost part of its area of outcrop (fig. 1). Fossiliferous micaceous arkosic sandstone occurs in the Alsea Formation near the southern limit of its area of outcrop, $5 \mathrm{~km}$ northeast of Yachats.

A distinctive siltstone unit occurs in the uppermost part of the sequence along the southwest side of Alsea Bay. It consists of more than $350 \mathrm{~m}$ of particularly well indurated massive dark-gray ironstained tuffaceous glauconitic siltstone containing scattered calcareous nodules and numerous resistant tuff interbeds $2-20 \mathrm{~cm}$ thick.

Beds of medium- to dark-greenish-gray medium-grained glauconitic sandstone $1 / 2-8 \mathrm{~m}$ thick are common in the Alsea Formation. They are generally massive and weather to a mottled bluish green and orange brown. In places they contain mollusks stained by iron oxide. The 


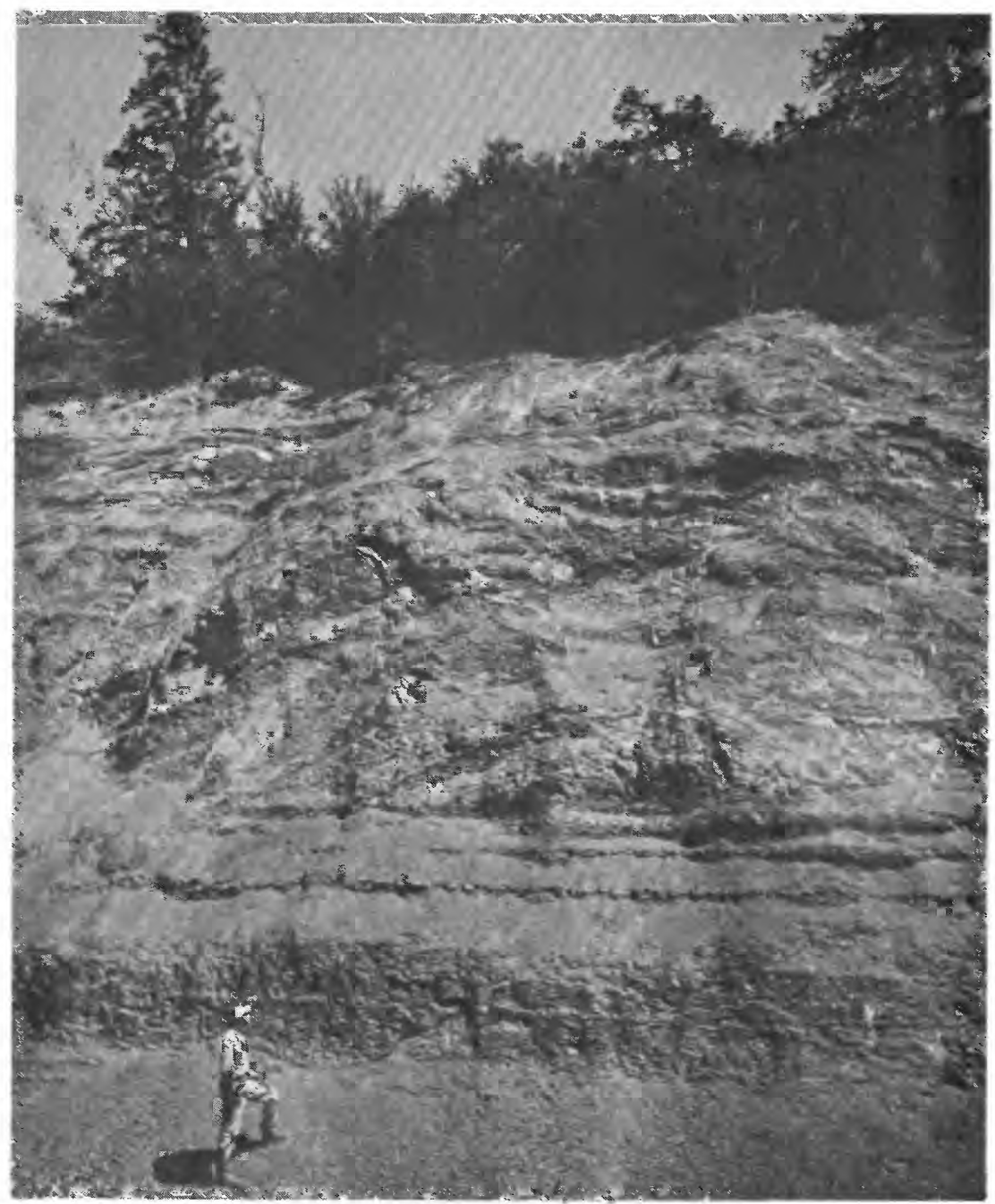

FIGURE 4.-Tuffaceous siltstone and sandstone of the Alsea Formation in its type section on the north side of Alsea Bay.

glauconitic sandstone contains minor plagioclase, quartz, volcanic clasts, calcite, siderite(?), and opaque minerals. An 8-m-thick sandstone bed on the north side of Alsea Bay $100 \mathrm{~m}$ east of the U.S. Highway 101 bridge abutment (G, fig. 2) and several other beds contain as much as 90 percent glauconite. A chemical analysis of this glauconitic sandstone is shown in table 1, column 1 . Scattered grains of glauconite commonly occur in the tuffaceous siltstone (in places replacing Foraminifera) and sandstone, and less commonly in tuff beds. 
Feldspathic sandstone in the Alsea Formation contains ubiquitous altered glass shards (fig. 5) and common andesitic and dacitic lithic fragments. Plagioclase, the most abundant clast type, commonly shows progressive and oscillatory zoning and is derived principally from volcanic rocks of intermediate composition. Other major constitutents include quartz, alkali feldspar, and glauconite and other clay minerals. Minor constituents include green hornblende, augite, hypersthene, opaque minerals, hydrous iron oxides, muscovite, biotite, chlorite, and apatite. Many sandstones are cemented by secondary carbonate. The mineral grains are angular to subangular. Near-euhedral crystals of plagioclase are common, and many delicate protrusions on glass shards are preserved. Siltstones are similar in lithology to feldspathic sandstones, but commonly the content of altered glass shards is much higher in the siltstones.

Lithic sandstone consists principally of andesitic to dacitic grains that show flow banding and contain plagioclase phenocrysts. Grains of altered glass with stretched or collapsed bubbles are abundant in some rocks. The matrix of the lithic sandstones is composed of finely comminuted volcanic grains, broken plagioclase crystals, and altered glass shards. The volcanic grains are texturally and mineralogically different from Eocene volcanic rocks in the Coast Range and probably had a Cascade provenance.

In addition to the high content of glass shards and fine tuff interbeds, the Alsea Formation contains beds of lapilli tuff such as along the east side of Lint Slough south of Alsea Bay (fig. 2). These beds consist of subrounded to subangular fragments of pumice and andesitic and dacitic volcanic rocks. A 10-m-thick lapilli tuff bed on the east side of Lint Slough grades upward from volcanic clasts $1-8 \mathrm{~cm}$ in diameter at the base into pumiceous lapilli and fine-grained tuff.

The chemical analyses for four typical samples of tuffaceous siltstone and fine-grained sandstone and one fine-grained tuff bed in the Alsea Formation are given in table 1. The chemical composition of the Alsea reflects the high percentage of glass shards and felsic volcanic glass derived from contemporaneous volcanism in an ancestral Cascade Range along the east margin of the basin (Snavely and Wagner, 1963).

\section{AGE AND DEPOSITIONAL ENVIRONMENT}

Molluscan assemblages of provincial Oligocene age occur throughout the Alsea Formation, but they are most common and are of greatest taxonomic diversity in the sandier strata. The Alsea Bay and Yaquina River sections of the Alsea Formation are of regional biostratigraphic significance because they contain the boundary between the provincial middle and late Oligocene. In the type section, the early and middle 


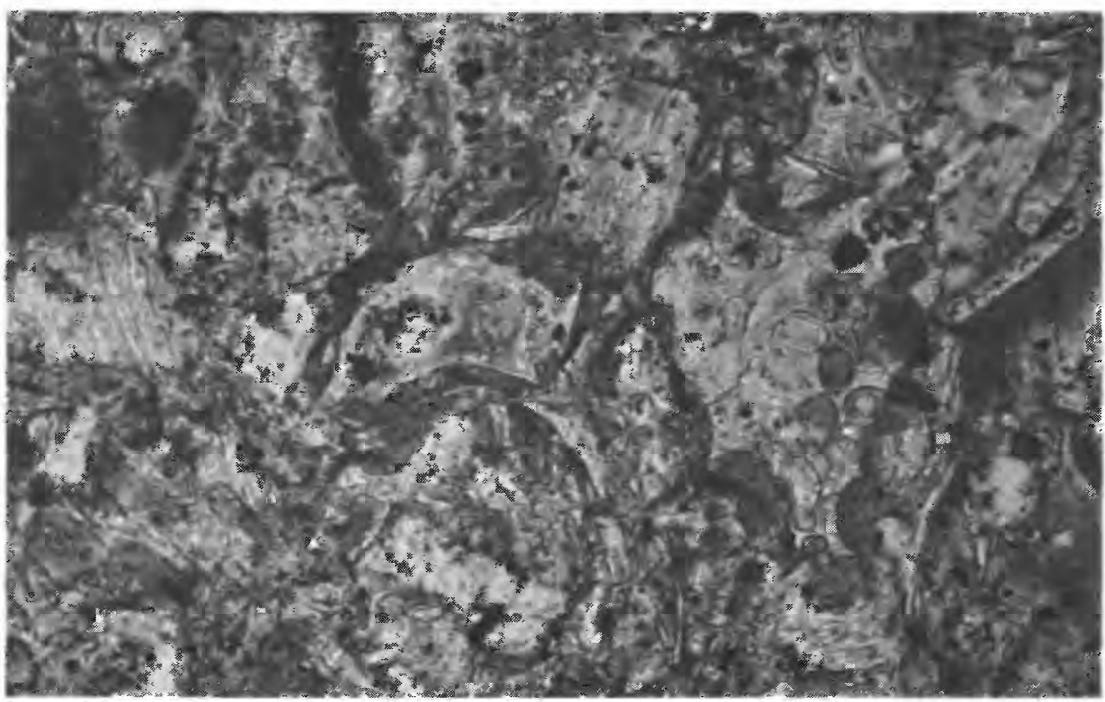

FIGURE 5.-Photomicrograph showing the abundant vesicular glass fragments and glass shards that characterize siltstone and sandstone of the Alsea Formation. Width of photomicrograph is $0.5 \mathrm{~mm}$ in thin section.

TABLE 1.-Chemical analyses of selected sedimentary rocks from the Alsea Formation

\begin{tabular}{|c|c|c|c|c|c|c|}
\hline & 1 & 2 & 3 & 4 & 5 & 6 \\
\hline $\mathrm{SiO}_{2}$ & 51.4 & 63.0 & 61.6 & 60.0 & 58.5 & 56.5 \\
\hline $\mathrm{Al}_{2} \mathrm{O}_{3}$ & 7.8 & 13.7 & 13.7 & 13.8 & 14.9 & 14.0 \\
\hline $\mathrm{Fe}_{2} \mathrm{O}_{3}$ & 13.0 & 1.2 & 3.8 & 4.4 & 4.0 & 5.8 \\
\hline $\mathrm{FeO}$ & 5.6 & .44 & 1.7 & 1.6 & 1.7 & 1.5 \\
\hline $\mathrm{MgO}_{-}$ & 2.3 & 1.2 & 1.5 & 1.8 & 1.5 & 1.7 \\
\hline $\mathrm{CaO}$ & 1.0 & 3.3 & 2.2 & 3.1 & 2.2 & 4.1 \\
\hline $\mathrm{Na}_{2} \mathrm{O}$ & .87 & .94 & 1.4 & 1.3 & 1.1 & 2.0 \\
\hline $\mathrm{K}_{2} \mathrm{O}$ & 4.9 & 1.9 & 2.2 & 1.8 & 1.2 & 1.6 \\
\hline $\mathrm{H}_{2} \mathrm{O}-$ & 5.0 & 6.6 & 6.1 & 5.0 & 9.1 & 5.0 \\
\hline $\mathrm{H}_{2} \mathrm{O}+$ & 4.5 & 6.7 & 4.2 & 5.4 & 4.1 & 5.4 \\
\hline $\mathrm{TiO}_{2}$ & .56 & .82 & .75 & .88 & .70 & 1.1 \\
\hline $\mathrm{P}_{2} \mathrm{O}_{5}$ & .19 & .13 & .17 & .18 & .12 & .24 \\
\hline $\mathrm{MnO}$ & .04 & .04 & .05 & .04 & .06 & .15 \\
\hline $\mathrm{CO}_{2}$ & 2.1 & $<.05$ & $<.05$ & .57 & .12 & 1.1 \\
\hline
\end{tabular}

1. Glauconitic sandstone, $\mathrm{SE}^{1 / 4} \mathrm{SW} 1 / 4$, sec. $18, T$. $13 \mathrm{~S}$., R. $11 \mathrm{~W}$., Waldport quadrangle.

2. Tuff, 1 -m-thick bed, SW1/4, sec. 19 , T. 13 S., R. 11 W., Waldport quadrangle.

3. Tuffaceous siltstone, center sec. 10, T. 8 S., R. 11 W., Cape Foulweather quadrangle.

4. Tuffaceous siltstone, $\mathrm{SE}^{1 / 4} \mathrm{NW} 1 / 4$, sec. $18, \mathrm{~T}$. $11 \mathrm{~S}$., R. $10 \mathrm{~W}$., Toledo quadrangle.

5. Tuffaceous siltstone, center NE1/4, sec. 35, T. 11 S., R. 11 W.. Toledo quadrangle,

6. Tuffaceous siltstone, $\mathrm{SW}^{1 / 4} \mathrm{NW}^{1 / 4}$, sec. 7 , T. $11 \mathrm{~S}$., R. $10 \mathrm{~W}$., Toledo quadrangle.

Oligocene Lincoln Stage of Weaver and others (1944) is represented by assemblages from the lower exposed part of the formation along the north shore of Alsea Bay (between G and B, fig. 2). These assemblages are also referable to the upper part of the Refugian Stage of Schenck and Kleinpell (1936), a unit based on both molluscan and foraminiferal data. Molluscan assemblages from the upper part of the type section, 
along the north shore of Alsea Bay between $\mathrm{A}$ and $\mathrm{G}$ and south shore between $\mathrm{C}$ and $\mathrm{D}$ in figure 2, are referable to the lower part of the Blakeley Stage of Weaver and others (1944) of provincial late Oligocene age (Addicott, 1972).

At Alsea Bay, "Lincoln Stage" mollusks occur in an interval from about 430 to $760 \mathrm{~m}$ above the base of the exposed section on the north side of the bay (between G and B, fig. 2). One of the most characteristic species in these assemblages is the "Lincoln," and upper Refugian, index species Bruclarkia columbiana (Anderson and Martin) (fig. $6 A$ ). Other mollusks indicative of assignment to the "Lincoln Stage" include Acila shumardi (Dall), Parvicardium lincolnensis (Weaver) (fig. 6D), Macrocallista pittsburgensis Dall (fig. 6F), Priscofusus chehalisensis (Weaver) (fig. 6G), and Turritella porterensis Weaver (fig. $6 \mathrm{H}$ ). The uppermost $340 \mathrm{~m}$ of the Alsea Bay section (north shore between $A$ and $G$, south shore between $C$ and $D$, fig. 2) are referable to the lower upper Oligocene part of the "Blakeley Stage." The lowest stratigraphic occurrence of mollusks of the "Blakeley Stage" is in an 8-m-thick glauconitic sandstone on the north side of the bay about 100 m east of U.S. 101 highway bridge over Alsea Bay (G, fig. 2). A small, shallow-water assemblage from this bed includes Bruclarkia acuminata (Anderson and Martin) (fig. $6 B, K$ ) and Priscofusus stewarti (Tegland) (fig. 6I), gastropods restricted to the "Blakeley Stage." Stratigraphically higher assemblages from southwest of Waldport include Liracassis rex (Tegland) (fig. 6C, E) and Acila gettysburgensis (Reagan) (fig. 6J). The biozone of $L$. rex is restricted to the lower part of the "Blakeley Stage" (Durham, 1944).

The much thinner reference section exposed along the Yaquina River, about $17 \mathrm{~km}$ to the north, provides additional biostratigraphic control. A diverse assemblage referable to the "Lincoln Stage" occurs within $80 \mathrm{~m}$ stratigraphically of the contact with the underlying Nestucca Formation (M2, fig. 3), and mollusks referable to the lower part of the "Blakeley Stage" occur within $35 \mathrm{~m}$ of the contact with the overlying Yaquina Formation (M1, fig. 3).

The "Lincoln" or Refugian molluscan assemblages from the lower part of the Alsea Formation along the Yaquina River and from the middle part of the formation at Alsea Bay represent middle sublittoral, or neritic, depths. Molluscan assemblages in the $160 \mathrm{~m}$ of section below the glauconitic sandstone (G, fig. 2) on the north side of Alsea Bay suggest shallowing to depths of about $20-30 \mathrm{~m}$ near the top of the middle part of the formation. The foraminiferal fauna from this interval also indicates shallow-water depths. This fossiliferous sandstone appears to be a very shallow-water, inner sublittoral deposit with abundant specimens of Crepidula ungana Dall that form stacks and coils and a Mytilus similar to the modern bay mussel $M$. edulis Linné. 
Stratigraphically higher molluscan assemblages along the southwest shore of Alsea Bay (between C and D, fig. 2) are characterized by very low diversity and by genera indicative of marked deepening to outer sublittoral or upper bathyal depths. Mollusks from within $35 \mathrm{~m}$ of the contact with the overlying Yaquina Formation at Yaquina River indicate shallowing again to inner sublittoral depths, possibly 10-15 m. The foraminiferal faunas also suggest shallow-water depths near the upper contact.

Foraminifera are abundant and varied throughout much of the Alsea Formation and therefore particularly useful in placing the formation in the Pacific coast biostratigraphic framework. Foraminifera from the lower part of the Alsea Formation are referable to the Refugian Stage of Schenck and Kleinpell (1936) and those from the upper part of the formation to the Zemorrian Stage of Kleinpell (1938).

Some of the more characteristic and commonly occurring forms of the lower part of the Alsea Formation assigned to the Refugian Stage are as follows:

Cassidulina galvinensis Cushman and Frizzell

Ceratobulimina washburnei Cushman and Schenck

Cibicides elmaensis Rau

Epistomina eocenica (Cushman and Hanna)

Guttulina spp.

Plectofrondicularia packardi packardi Cushman and Schenck

Robulus spp. \{large\}

Sigmomorphina aff. S. schencki Cushman and Ozawa

Spiroloculina texana Cushman and Ellison

Uvigerina cocoaensis Cushman

The Zemorrian Stage of Kleinpell (1938) is well represented in the upper part of the formation. Some of the more common and characteristic species from that part of the formation are as follows:

Bolivina marginata adelaidana Cushman and Kleinpell

Buccella mansfieldi oregonensis (Cushman and R.E. and K.C. Stewart)

Buliminella bassendorfensis Cushman and Parker

Cassidulinoides cf. C. californiensis Bramlette

Cibicides elmaensis Rau var. A.

Entosolenia sp.

Nonion cf. $N$. incisum kernensis Kleinpell

Robulus brevispinosus (Nuttall)

Uvigerina obesa impolita Cushman and Laiming

Virgulina cf. $V$. bramlettei Gailoway and Morrey

Although the Refugian-Zemorrian boundary is gradational in places, it is well defined in the Alsea's type section at Alsea Bay. Cassidulina crassipunctata, Nonion cf. $N$. incisum kernensis, and 
$N$
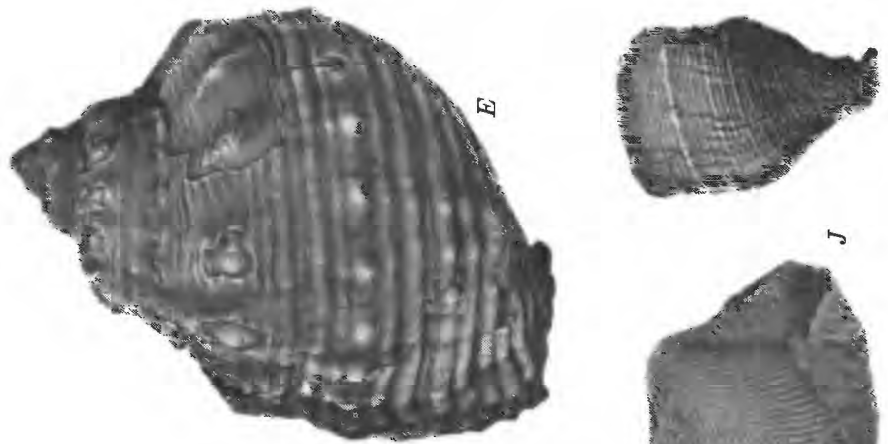

$Q$
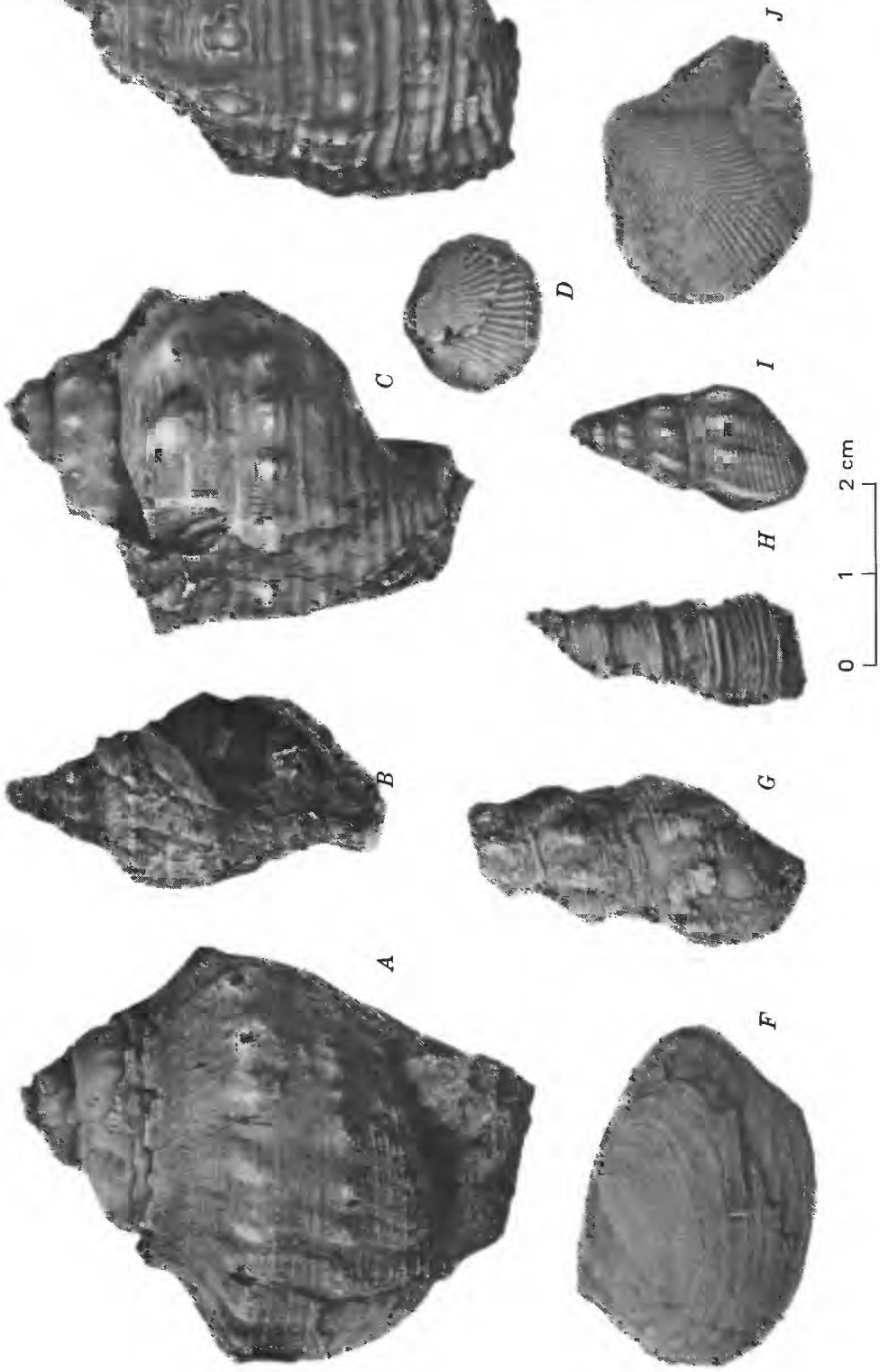
ه广

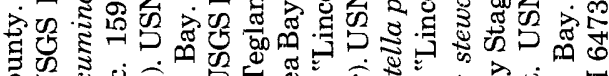

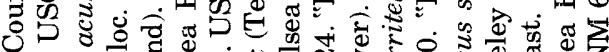

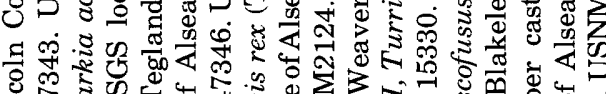

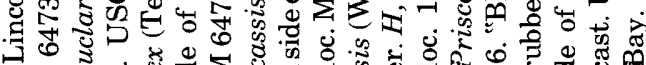

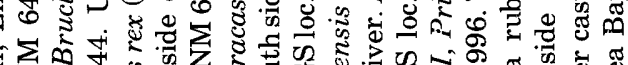

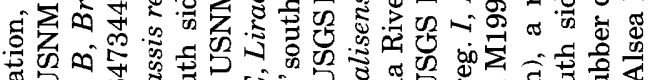

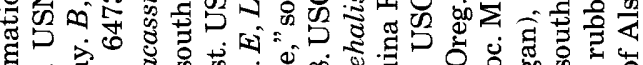

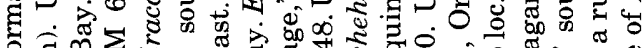

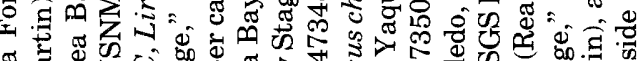
ஐ

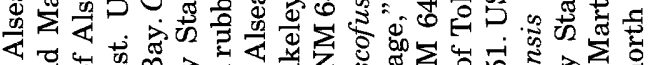

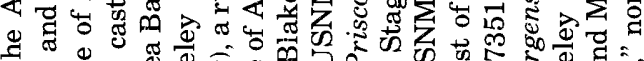

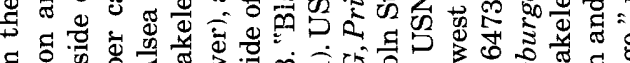
द

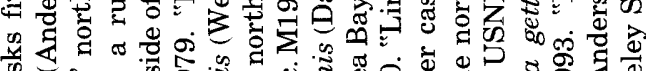
की

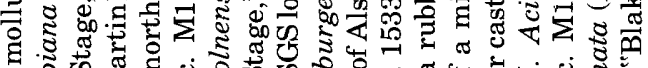
द्व \& 8 .

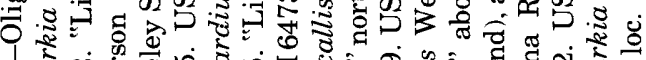

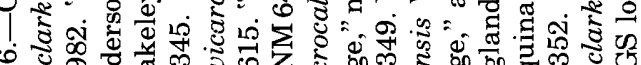

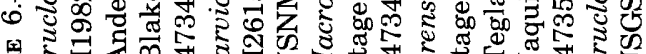

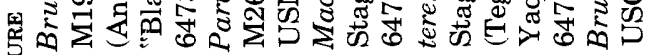
尊 
Buccella mansfieldi oregonensis are rarely found below the Zemorrian Stage in Pacific coast Tertiary sequences. In the Alsea Bay section, the lowest occurrence of these species (S, fig. 2) is approximately $15 \mathrm{~m}$ below the base of the 25-m-thick sandstone bed exposed on the north side of the bay. Most of the foraminiferal species known to be characteristic of the Refugian Stage are not found above this horizon. A molluscan fauna characteristic of the Refugian Stage, however, occurs approximately $90 \mathrm{~m}$ stratigraphically higher than the position of the Refugian- Zemorrian boundary indicated by Foraminifera.

Neither the base of the Refugian Stage nor the top of the Zemorrian Stage is represented in the Alsea Formation in either the Alsea Bay section or the Yaquina River section. Locally, however, the formation may extend down into the lower part of the Refugian Stage, for a few species commonly known in that part of the stage, such as Uvigerina cocoaensis and Vaginulinopsis saundersi, do occur in the lower part of the formation at Alsea Bay. Only a few poorly preserved and nondiagnostic foraminiferal assemblages have been found in the lower $400 \mathrm{~m}$ of the formation exposed in the Alsea Bay section.

The lower $650 \mathrm{~m}$ of the Alsea Formation in the Alsea Bay section is referred to the Refugian Stage, whereas only about the lower $60 \mathrm{~m}$ of the formation exposed in the Yaquina River section is placed in the Refugian Stage. Thinning of the lower (Refugian) part of the Alsea Formation in the Yaquina River section is interpreted as resulting from a slower sedimentation rate across a broad high that existed in this area in late Eocene to middle Oligocene time (Snavely and others, 1972b). The Nestucca Formation, which conformably underlies the Alsea Formation, also is thinner in the Yaquina River area than in adjacent areas.

The uppermost part of the Zemorrian Stage is represented in the superjacent Yaquina Formation. The occurrence of such forms as Virgulina cf. V. bramlettei, Cassidulinoides cf. C. californiensis, and Nonion cf. $N$. incisum kernensis in the Alsea Formation at Alsea Bay suggests that the Alsea may also extend up into the upper part of the Zemorrian Stage.

Most workers now place the lower part of the Refugian Stage in the uppermost part of the Pacific coast Eocene sequence and the upper part of the Refugian Stage and all of the Zemorrian Stage in the Oligocene (Kleinpell and Weaver, 1963). On this basis, the Alsea Formation is Oligocene. The lowest part of the type Alsea, however, contains a few foraminiferal species that suggest a latest Eocene age.

Foraminiferal assemblages of the Alsea Formation compare very well with, and therefore suggest correlation with, those known in a number of other areas of the Pacific Northwest. Faunas of the Lincoln Creek Formation of southwest Washington, particularly those of the 
local Cassidulina galvinensis zone and Pseudoglandulina aff. $P$. inflata zone (Beikman and others, 1967), are very similar to the Foraminifera of the Alsea Formation. Foraminiferal faunas from the lower part of Weaver's (1912) type Blakeley Formation of the Puget Sound area, the middle and upper parts of the Twin River Formation of the northern Olympic Peninsula (Rau, 1964), and an Oligocene sequence exposed on the southwestern part of Vancouver Island between Port San Juan and Carmanah Point are very similar to the faunas of the Alsea Formation.

Moderate water depths are suggested by the faunas of the lower (Refugian) part of the formation at Alsea Bay (S to B, fig. 2), where abundant Gyroidina orbicularis planata, Cassidulina galvinensis, Ceratobulimina washburnei, costate Uvigerina, and other relatively deepwater forms occur. Although upper bathyal depths may have existed for a short time, faunas of the lower part of the formation mostly represent an outer-shelf environment. The characteristic robust size of the Foraminifera in this part of the formation suggest optimum conditions for their development and an abundance of nutrients. Unusually large Foraminifera are typical of many of the faunas of the Refugian Stage in the Pacific Northwest from westcentral Oregon to as far north as southern Vancouver Island, suggesting that a similar shelf environment extended throughout these areas.

Water depths became progressively shallower in the early part of the Zemorrian Stage, as inner sublittoral conditions are indicated by the occurrence of Elphidum aff. E. californicum and Nonion cf. $N$. incisum kernensis in the middle part of the formation (A to S, fig. 2). The upper part of the Alsea Formation on Alsea Bay (C to D, fig. 2) was deposited in an outer sublittoral or possibly an upper bathyal environment, as indicated by the occurrence of Gyroidina orbicularis planata and Cassidulina crassipunctata; in contrast, the uppermost part of the Alsea Formation on the Yaquina River (fig. 3) contains Foraminifera typical of an inner sublittoral environment. This difference suggests that the basin deepened southward from the Yaquina River at the time the sediments of the upper part of the Alsea Formation were being deposited. Deepening in this direction is also consistent with the interpretation that shallow water deltaic sands in the lower part of the Yaquina Formation are equivalent to the deeper water siltstone of the upper part of the type Alsea Formation.

In summary, the Refugian and Zemorrian foraminiferal assemblages of the Alsea Formation generally suggest an offshore shelf-type environment which became nearly littoral at times, especially during the deposition of the middle part of the formation on Alsea Bay and uppermost part of the formation on the Yaquina River. Water temper- 
atures were cool, considering the shallow depths represented by parts of the formation.

\section{REGIONAL CORRELATIONS AND PALEOGEOLOGY}

The Alsea Formation represents part of a continental shelf facies of Oligocene age that was widespread in western Oregon and Washington (fig. 7). Marine sequences that correlate with the Alsea Formation in the Oregon Coast Range include the Eugene Formation (Smith, 1924) on the southeast flank and the Pittsburgh Bluff Formation (Schenck, 1927) and the upper part of the Keasey Formation (Schenck, 1927; Moore and Vokes, 1953) in the northern part. In Washington, correlative units include the Lincoln Creek Formation (Weaver, 1937; Beikman and others, 1967) in the southwestern part, the lower part of the Blakeley Formation (Weaver, 1912) in northern Puget Sound, and the middle and upper members of the Twin River Formation (Arnold and Hannibal, 1913; Brown and Gower, 1958) of the northeastern Olympic Peninsula. Neritic sedimentary rocks of Oligocene age also crop out along the south side of Vancouver Island, British Columbia, between Port San Juan and Carmanah Point.

Deepwater Oligocene strata are exposed in the northwestern Olympic Peninsula, across the Straits of Juan de Fuca from correlative shallow-water marine sedimentary rocks of Vancouver Island. These include the middle and upper members of the Twin River Formation between Port Angeles and Clallam Bay (Brown and others, 1960; Gower, 1960) and unnamed strata exposed farther west between Clallam Bay and Cape Flattery, where about 3,000 m of Oligocene siltstone with interbedded units of turbidite sandstone contain a foraminiferal fauna indicative of bathyal depths. A steep Oligocene continental slope that separated deep marginal basin deposits of the northwestern Olympic Peninsula from shelf deposits of Vancouver Island probably lay along the western part of the Straits of Juan de Fuca and swung southward near Port Angeles (fig. 7) Sparse subsurface information suggests that deepwater deposits of Oligocene age probably formed in the area of the present Continental Shelf of Oregon and Washington as shown in the paleogeologic map, figure 7.

The abundant volcanic detritus in the Alsea Formation differs chemically and petrographically from Eocene volcanic rocks of the Coast Range but is similar to some of the Oligocene volcanic rocks from the western Cascades described by Peck, Griggs, Schlicker, Wells, and Dole (1964). It is therefore likely that vigorous pyroclastic volcanism occurred in an ancestral Cascade Range along the east margin of the shelf in Oligocene time. Great quantities of volcanic ash fell directly into the sea or was carried by streams to the marine environment. Some volcanic debris carried by streams to the margin of the basin was 


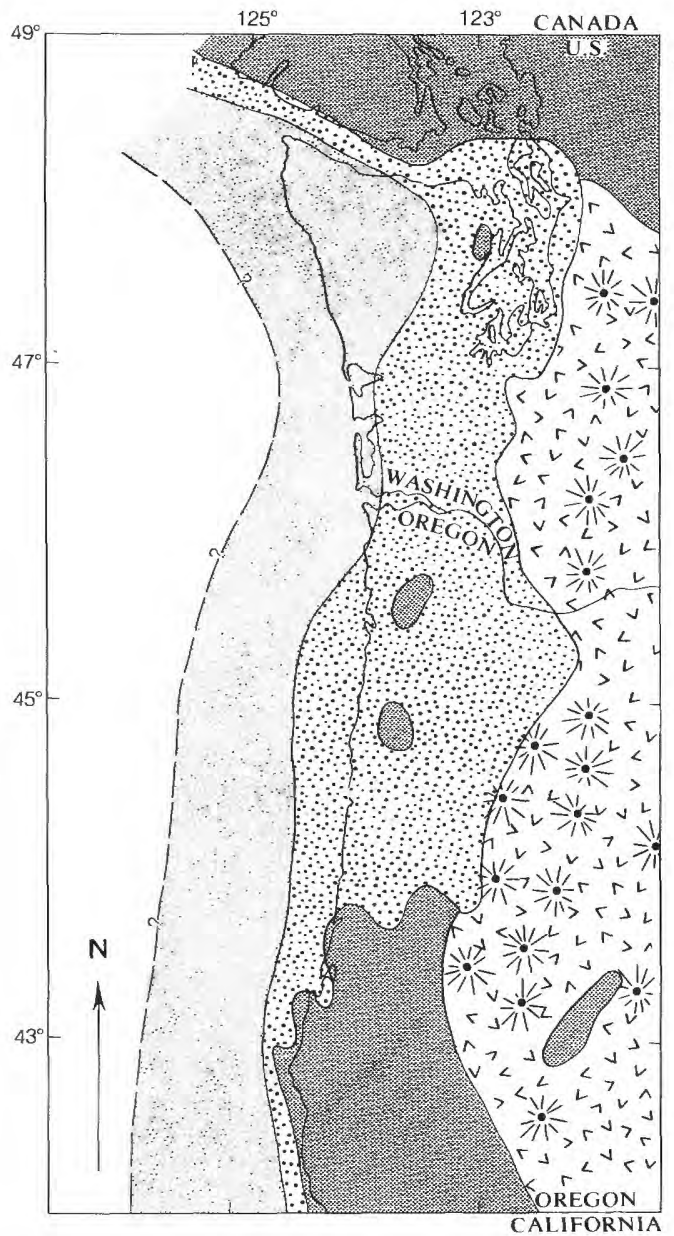

EXPLANATION

MARINE DEPOSITS

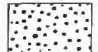

Tuffaceous sand and silt; shelf facies

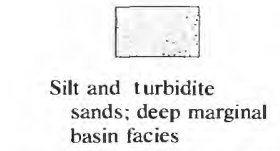

CONTINENTAL DEPOSITS

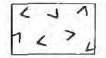

Pyroclastic and epiclastic debris

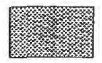

Pre-Oligocene rocks

Approximate contact

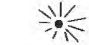

Volcanic vent

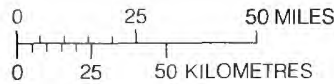

FIGURE 7.--Inferred distribution of Oligocene shelf and deepwater marginal basin facies in western Oregon and Washington and the adjacent continental margin.

transported into deeper water by submarine mudflows (Snavely and Wagner, 1963). Only a small amount of volcanic material reached the present site of the northwestern part of the Olympic Peninsula, as only a few thin tuff beds are present in the deepwater Oligocene sequence exposed there.

Deposition of the shelf sediments of the Alsea Formation and correlative stratigraphic units in western Oregon was terminated in late Oligocene time by regional uplift in the present site of the Oregon Coast Range. This uplift essentially restricted marine deposition to the west flank of the Coast Range and to the present Continental Shelf except for a restricted embayment that extended into the northern part of the Willamette trough. Several large westward flowing streams 
breached the ancestral Coast Range uplift and carried sand and gravel to form thick deltaic deposits near the present coast. One such deposit is represented by the upper Oligocene and lower Miocene Yaquina Formation. In western Washington only minor changes occurred in the early and middle Oligocene depositional environment, and shelftype sedimentation continued into late Oligocene time. Beyond the shelf, the deposition of sediments in the deep marginal basin off both Oregon and Washington was uninterrupted.

\section{REFERENCES CITED}

Addicott, W. O., 1972, Provincial middle and late Tertiary molluscan stage, Temblor Range, California, in Symposium on Miocene biostratigraphy of California: Soc. Econ. Paleontologists and Mineralogists, Pacific Sec., Bakersfield, Calif., p. 1-26, pls. 1-4.

Arnold, Ralph, and Hannibal, Harold, 1913, The marine Tertiary stratigraphy of the north Pacific Coast of America: Am. Philos. Soc. Proc., v. 52, no. 212, p. 559605.

Beikman, H. M., Rau, W. W., and Wagner, H. C., 1967, The Lincoln Creek Formation Grays Harbor Basin southwestern Washington: U.S. Geol. Survey Bull. 1244-I, $14 \mathrm{p}$.

Braislin, D. B., Hastings, D. D., and Snavely, P. D., Jr., 1971, Petroleum potential of western Oregon and Washington, in Cram, I. A., ed., Possible future petroleum provinces of North America: Am. Assoc. Petroleum Geologists Mem. 15, p. 229-238.

Brown, R. D., Jr., and Gower, H. D., 1958, Twin River formation (redefinition), northern Olympic Peninsula, Washington: Am. Assoc. Petroleum Geologists Bull., v. 42, no. 10, p. 2492-2512.

Brown, R. D., Jr., Gower, H. D., and Snavely, P. D., Jr., 1960, Geology of the Port Angeles-Lake Crescent area, Clallam County, Washington: U.S. Geol. Survey Oil and Gas Inv. Map OM-203.

Durham, J. W., 1944, Megafaunal zones of the Oligocene of northwestern Washington: California Univ. Pubs., Dept. Geol. Sci. Bull., v. 27, no. 5, p. 101-211, pls. 13-18.

Gower, H. D., 1960, Geologic map of the Pysht quadrangle, Washington: U.S. Geol. Survey Geol. Quad. Map GQ-129, scale 1:62,500.

Harrison and Eaton, 1920, The mineral resources of Oregon: Oregon Bur. Mines and Geology, v. 3, no. 1, p. 3-37.

Kleinpell, R. M., 1938, Miocene stratigraphy of California:Tulsa, Am. Assoc. Petroleum Geologists, $450 \mathrm{p}$.

MacLeod, N. S., and Snavely, P. D., Jr., 1973, Volcanic and intrusive rocks of the central part of the Oregon Coast Range: Oregon Dept. Geol. and Mineral Industries Bull. 77, p. 47-74.

Moore, R. C., and Vokes, H. E., 1953, Lower tertiary crinoids from northwestern Oregon: U.S. Geol. Survey Prof. Paper 233-E, p. 113-148.

Peck, D.L., Griggs, A. B., Schlicker, H. G., Wells, F. G., and Dole, H. M., 1964, Geology of the central and northern parts of the western Cascade Range in Oregon: U.S. Geol. Survey Prof. Paper 449, 56 p.

Rau, W. W., 1964, Foraminifera from the northern Olympic Peninsula, Washington: U.S. Geol. Survey Prof. Paper 374-G, 33 p., 7 pls., 2 figs.

Schenck, H. G., 1927, Marine Oligocene of Oregon: California Univ. Pubs., Dept. Geol. Sci. Bull., v. 16, no. 12, p. 449-460. 
1928, Stratigraphic relations of western Oregon Oligocene formations: California Univ. Pub., Dept. Geol. Sci. Bull., v. 18, no. 1, 50 p.

Schenck, H. G., and Kleinpell, R. M., 1936, Refugian stage of the Pacific coast Tertiary: Am. Assoc. Petroleum Geologists Bull., v. 20, no. 2, p. 215-225.

Smith, W.D., 1924, Petroleum possibilities of western Oregon: Econ. Geol., v. 19, p. 455-465.

Snavely, P. D., Jr., and MacLeod, N. S., 1974, Yachats Basalt-an upper Eocene differentiated volcanic sequence in the Oregon Coast Range: U.S. Geol. Survey Jour. Research, v. 2, no. 4 p. 395-403.

Snavely, P. D., Jr., MacLeod, N. S., and Rau, W. W., 1969, Geology of the Newport area, Oregon: Ore Bin, v. 31, nos. 2 and 3, p. 25-71.

Snavely, P. D., Jr., MacLeod, N. S., and Wagner, H. C., 1972a, Preliminary bedrock geologic map of the Cape Foulweather and Euchre Mountain quadrangles, Oregon: U.S. Geol. Survey open-file map, scale 1:48,000.

$-1972 \mathrm{~b}$, Preliminary bedrock geologic map of the Waldport and Tidewater quadrangles, Oregon: U.S. Geol. Survey open-file map, scale 1:48,000.

-1972c, Preliminary bedrock geologic map of the Yaquina and Toledo quadrangles, Oregon: U.S. Geol. Survey open-file map, scale 1:48,000.

Snavely, P. D., Jr., MacLeod, N. S., Wagner, H. C., and Rau, W. W., 1975a, Geology of the Cape Foulweather and Euchre Mountain quadrangles, Oregon: U.S. Geol. Survey Misc. Inv. Series Map 1-868 (in press).

$-1975 b$, Geology of the Waldport and Tidewater quadrangles, Oregon: U.S. Geol. Survey Misc. Inv. Series Map I-866 (in press).

-1975 c, Geology of the Yaquina and Toledo quadrangles, Oregon: U.S. Geol. Survey Misc. Inv. Series Map I-867 (in press).

Snavely, P. D., and Wagner, H. C., 1963, Tertiary geologic history of western Oregon and Washington: Washington Div. Mines and Geology Rept. Inv. 22, 25 p.

Vokes, H. E., Norbisrath, Hans, and Snavely, P. D., Jr., 1949, Geology of the NewportWaldport area, Lincoln County, Oregon: U.S. Geol. Survey Oil and Gas Inv. Prelim. Map 88.

Weaver, C. E., 1912, A preliminary report on the Tertiary paleontology of western Washington: Washington Geol. Survey Bull. 15, 80 p., 15 pls.

1937, Tertiary stratigraphy of western Washington and northwestern Oregon: Washington Univ. Pubs., Geology, v. 4, 266 p.

Weaver, C. E., and others, 1944, Correlation of the marine Cenozoic formations of western North America (Chart 11): Geol. Soc. America Bull., v. 55, 5, p. 569-598. 


